\title{
Behavioral and neurogenomic transcriptome changes in wild-derived zebrafish with fluoxetine treatment
}

\author{
Ryan Y Wong ${ }^{1 *}$, Sarah E Oxendine ${ }^{1}$ and John Godwin ${ }^{1,2}$
}

\begin{abstract}
Background: Stress and anxiety-related behaviors are seen in many organisms. Studies have shown that in humans and other animals, treatment with selective serotonin reuptake inhibitors (e.g. fluoxetine) can reduce anxiety and anxiety-related behaviors. The efficacies and side effects, however, can vary between individuals. Fluoxetine can modulate anxiety in a stereospecific manner or with equal efficacy regardless of stereoisomer depending on the mechanism of action (e.g. serotonergic or GABAergic effects). Zebrafish are an emerging and valuable translational model for understanding human health related issues such as anxiety. In this study we present data showing the behavioral and whole brain transcriptome changes with fluoxetine treatment in wild-derived zebrafish and suggest additional molecular mechanisms of this widely-prescribed drug.
\end{abstract}

Results: We used automated behavioral analyses to assess the effects of racemic and stereoisomeric fluoxetine on male wild-derived zebrafish. Both racemic and the individual isomers of fluoxetine reduced anxiety-related behaviors relative to controls and we did not observe stereospecific fluoxetine effects. Using RNA-sequencing of the whole brain, we identified 411 genes showing differential expression with racemic fluoxetine treatment. Several neuropeptides (neuropeptide $Y$, isotocin, urocortin 3, prolactin) showed consistent expression patterns with the alleviation of stress and anxiety when anxiety-related behavior was reduced with fluoxetine treatment. With gene ontology and KEGG pathway analyses, we identified lipid and amino acid metabolic processes, and steroid biosynthesis among other terms to be over-enriched.

Conclusion: Our results demonstrate that fluoxetine reduces anxiety-related behaviors in wild-derived zebrafish and alters their neurogenomic state. We identify two biological processes, lipid and amino acid metabolic synthesis that characterize differences in the fluoxetine treated fish. Fluoxetine may be acting on several different molecular pathways to reduce anxiety-related behaviors in wild-derived zebrafish. This study provides data that could help identify common molecular mechanisms of fluoxetine action across animal taxa.

Keywords: Fluoxetine, Anxiety, Stress, SSRI, Genomic, Brain, RNA-sequencing, Zebrafish, Serotonin, GABA

\section{Background}

Many organisms experience stress from natural sources such as territory defense, food competition, resource acquisition and exploration. In humans persistent extreme responses to stressful and anxiety-inducing situations or the inability to cope with such scenarios is a characteristic of an anxiety disorder [1]. Pharmacological studies indicate that anxiety and anxiety-related behaviors are

\footnotetext{
* Correspondence: ryan_wong@ncsu.edu

'Department of Biology, North Carolina State University, Box 7617, Raleigh, NC 27695-7617, USA

Full list of author information is available at the end of the article
}

associated with dysregulation of at least one of several major neurotransmitter systems in the brain: serotonergic (serotonin), GABAergic (gamma-aminobutyric acid), catecholaminergic (noradrenaline, dopamine) and glutamatergic (glutmate) systems [2,3]. Efficacies of various anxiolytic compounds, however, vary between individuals (both human and animal models) [4]. The extent to which this can be attributed to the nonselective or pleiotropic molecular aspects of the anxiolytic is unknown.

Selective serotonin reuptake inhibitors (SSRIs) are typically the first-line drugs prescribed for the alleviation of anxiety disorders in humans [5]. SSRI compounds (e.g.,

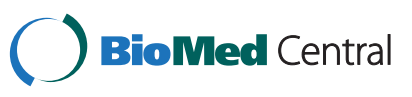


fluoxetine, citalopram, sertraline) block the serotonin transporter thus allowing for serotonin levels to remain high for longer periods of time in the synapse. Fluoxetine (tradename: Prozac) is a racemic mixture where both the $\mathrm{R}$ and $\mathrm{S}$ isomers effectively inhibit the serotonin transporter [6-10] and has also been demonstrated to have anxiolytic effects in rodents and fish [11,12]. While SSRIs are known to modulate serotonin levels, it has been shown that they also modulate production of neurosteroids (e.g. allopregnanolone) that act as modulators of GABA receptors [13-16]. In fluoxetine, Sfluoxetine induces greater allopregnanolone production in rodent brains than the $\mathrm{R}$ isomer $[6,14]$. Increasing allopregnanolone levels in rodents has been associated with decreases in aggression and anxiety [6,15,17-23]. In addition, SSRIs also affect various neuropeptide levels (e.g., neuropeptide Y, oxytocin, arginine vasopressin), which independently can modulate stress and anxiety levels [24]. Our laboratory has shown fluoxetine can affect expression of neuropeptide genes in teleosts [25] Hence SSRIs appear to affect many systems and understanding the full extent of changes in molecular mechanisms underlying fluoxetine mediated reduction in anxiety and stress is needed.

To understand the mechanisms underlying stress and anxiety, animal models used are highly inbred (i.e., domesticated) or selectively bred to exhibit extreme behavioral and physiological responses to stressful and anxiety-inducing contexts [2,11,26-29]. Although rodents have been primarily used as animal models for anxiety [2,26], zebrafish (Danio rerio) is an emerging system and valuable translational model for understanding stress and anxiety-related behaviors [30-35]. Similar to rodents, highly inbred lines of zebrafish show differences in baseline levels of stress and anxiety as well as responses to anxiolytics $[2,4,11,12,36,37]$. Zebrafish share similar neurochemistry, and behavioral and physiological responses to both anxiolytic and anxiogenic drugs as mammals [11,30,31]. Several neurotransmitter systems thought to be modulated in stress and anxiety (e.g., catecholamines, serotonin) in mammals are also described in zebrafish [32,38,39]. Zebrafish possess genes that encode serotonin transporters homologous to those of tetrapods, and the transporters have been shown to transport serotonin across cell membranes and the activity can be reduced with a SSRI in vitro [40]. Further, SSRI binding kinetics to the serotonin transporter in teleosts are similar in magnitude to rats [41]. Adult domesticated zebrafish also show reduced anxiety-related behaviors and cortisol levels when treated with fluoxetine [11]. Larval zebrafish treated with fluoxetine show changes in molecular pathways associated with stress response [42], but very little is known of the gene expression changes in adults. Hence, in addition to the zebrafish system's amenability for genetic manipulations and high throughput drug screening [43-45], the zebrafish represents a powerful model to explore molecular mechanisms of stress and anxiety-related behaviors.

In this study we assess the effects of chronic fluoxetine treatment on behavior and the neural transcriptome of adult wild-derived male zebrafish (High Stationary Behavior line, HSB, [29]). The HSB line shows consistently high levels of stress and anxiety-related behaviors across multiple assays [29]. Given documented stereospecific fluoxetine effects on aggressive behavior and anxietymediated neurochemical pathways in rodents [14,21], we test whether anxiety-related behaviors can be modulated stereospecifically in zebrafish by administering racemic, R-fluoxetine, and S-fluoxetine. To analyze the underlying mechanism of fluoxetine-induced anxiolytic effects of behavior, we use RNA-sequencing and test for wholebrain differential expression of protein-coding genes between racemic fluoxetine treatment and control. Through both behavioral and gene expression analyses, we show that fluoxetine alters both behavior and neurogenomic profiles.

\section{Methods}

\section{Pharmacological manipulation}

Male zebrafish from our selectively bred High Stationary Behavior line (see [29] for line characteristics) were subjected to one of four treatments: a racemic mixture of fluoxetine ( $\mathrm{n}=30)$, R-fluoxetine $(\mathrm{n}=12)$, S-fluoxetine ( $\mathrm{n}=12$ ), or our solvent (water) as a control $(\mathrm{n}=42)$. Studies in other teleosts have shown that waterborne fluoxetine enters the brain and has an approximate half life of nine and three days in the fish and water containing fish, respectively [46-48]. Testing of the racemic and stereoisomer treatment groups were separated by two months.

The first set of experiments involved treating zebrafish with a racemic fluoxetine mixture or the vehicle control. Treatment duration and racemic fluoxetine concentration follow a previously established protocol [11]. Briefly, fish were chronically treated with $100 \mu \mathrm{g} / \mathrm{L}$ of racemic fluoxetine (Sigma). As it has been previously demonstrated that two weeks of exposure to racemic fluoxetine alters behavior and cortisol levels [11], we assessed whether behavioral changes can be detected on a shorter time scale and thus behaviorally tested fish ( $\mathrm{n}=12$, see below) treated for one week. However, to be consistent with methods in the literature and to make our gene expression results comparable with previous studies, we treated a different set of fish $(\mathrm{n}=18)$ with racemic fluoxetine for two weeks. During treatment, the fish were housed in $2 \mathrm{~L}$ tanks in groups of six with constant aeration and fed ad libitum daily with commercial food (Tetramin). Every two days, we replaced all of the 
holding water of the fish with fresh system water (water used for normal housing) containing $100 \mu \mathrm{g} / \mathrm{L}$ racemic fluoxetine. Control fish $(\mathrm{n}=42)$ underwent identical procedures with the exception that the solvent (water) was added to the tanks. For the second set of experiments we administered isomers of fluoxetine and controls to a different set of fish. Fish treated with a stereoisomer of fluoxetine were handled exactly the same way as above, but were treated at a concentration of $33 \mu \mathrm{g} / \mathrm{L}$ for two weeks. As no previous study has administered isomers of fluoxetine in teleosts, our goal was to identify a dose that would maximize the opportunity to observe differences in the behavioral effects of the two isomers in the same manner conducted in rodents [21]. We determined that $33 \mu \mathrm{g} / \mathrm{L}$ is a biologically relevant dose through pilot dose-response analysis where we treated individuals for two weeks as described above but at four different concentrations (Additional file 1: Figure S1). We experienced minimal deaths and all fish consumed food during the treatment period, which suggests all were in good health (final sample size: racemic fluoxetine $(\mathrm{n}=28)$, R-fluoxetine $(\mathrm{n}=11)$, S-fluoxetine $(\mathrm{n}=11)$, control $(\mathrm{n}=37))$.

A subset of fish were treated with racemic fluoxetine $(\mathrm{n}=18)$ or water (control, $\mathrm{n}=18)$ but did not undergo behavioral testing. These fish were decapitated and brains removed and stored in RNAlater (Ambion) until processing for either RNA-sequencing or qRT-PCR (see below). The remaining racemic fluoxetine treated fish, those treated with a fluoxetine isomer and control fish were behaviorally tested (see below). All fish used in this study were sexually mature, 7 - 11 months old, and five generations removed from the wild with the exception of a subset of males used in the qRT-PCR experiment, which were sixth generation.

\section{RNA-sequencing analysis}

Using RNA-sequencing, we quantified whole-brain transcriptome levels in male zebrafish (five generations removed from the wild) treated with a racemic mixture of fluoxetine $(\mathrm{n}=9)$ and control animals $(\mathrm{n}=10)$. We extracted RNA using RNeasy Plus Mini Kit (Qiagen) according to the manufacturer's protocol. Since we wanted to assess a general effect of fluoxetine on gene expression, we pooled one microgram of total RNA from each individual in a treatment (e.g. one pooled sample for fluoxetine-treated and control fish). RNA quality was assessed with an Agilent 2100 Bioanalyzer (Agilent) and all samples had RNA integrity numbers (RIN) above 8.5. RNA samples were then submitted to the Genomic Sciences Laboratory at North Carolina State University, for cDNA library preparation (TruSeq RNA Sample Prep v2, Illumina) and 72 bp single-end RNA-sequencing (Illumina GAIIx). Following a balanced block design [49], both samples were multiplexed and run across three lanes. During analysis we combined reads across all lanes that passed default quality control filters (Illumina), which generated approximately 30.6 million reads for each of the control and fluoxetine-treated groups. Reads were aligned to the Danio rerio genome (assembly Zv9 [35], release 68) using GSNAP [50] with default parameters. We used Cufflinks (ver 2.0.1, [51-53]) to assess differential expression of protein-coding genes between control and fluoxetine-treated fish employing the program's multi-read and fragment bias correction. We used gProfiler [54,55] to determine significantly over-enriched Gene Ontology (GO) terms and Kyoto Encyclopedia of Genes and Genomes (KEGG) pathways. In Cufflinks and gProfiler we utilized the default false discovery rate (FDR) corrections. Statistical significance was assessed when $\mathrm{p}_{\text {FDR-corrected }}<0.05$.

\section{Real-time PCR validation analysis}

We assessed the expression of seven genes (prl2, npy, oxtl, slc6a4a, slc6a4b, slc6a11, ucn3l) associated with anxiety-like behaviors in other organisms, two genes showing more than two fold differences (isg15, nrbf2) in expression between treatments, and one housekeeping gene (ef1a) using quantitative reverse transcriptase PCR (qRT-PCR). Of these genes prl2, npy, oxtl, slc6a11, ucn $3 l$, isg 15 , and $n r b f 2$ were differentially regulated with RNA-sequencing (see below). We used 12 fish treated with racemic fluoxetine and 12 control fish. Six fish in each treatment group were independent from those used in RNA-seq analysis (six generations removed from the wild). Total RNA from all brains was extracted following the same protocol used for RNA-sequencing preparations (see above). Genomic DNA was removed by column filtration according to manufacturer's protocol (RNeasy Plus Mini kit, Qiagen). We subsequently quantified the RNA using Quant-iT RiboGreen (Invitrogen). Eight microliters of total RNA from each individual was reverse transcribed into cDNA using SuperScript III First-Strand Synthesis System for qRT-PCR (Invitrogen) according to modified manufacturer's protocol where the sample was primed with both random hexamers and oligo $(\mathrm{dT})_{20}$ primers. The cDNA was then purified using Amicon Ultracentrifugal filters (Millipore) according to the manufacturer's protocol [56-58]. The resulting purified samples were topped off to $100 \mu$ l total volume with Nuclease-Free water (Ambion).

The qRT-PCR was run on an ABI 7900HT Fast RealTime PCR system (Applied Biosystems) using SYBR green detection chemistry (SYBR Select, Applied Biosystems). The primers were designed using Primer-BLAST (NCBI) and primers either spanned exon-exon junctions or the amplicon spanned exons where the intron region was over one kilobase. Each sample was run in triplicate (see Additional file 2: Table S1 for primer sequences, amplicon 
lengths, and qRT-PCR reaction parameters). We normalized gene expression relative to a housekeeping gene (ef1a) and assessed differential expression using commercial software (REST 2009 [59], Qiagen). Our housekeeping gene has been shown to be stable across sex, tissue types, age, and chemical treatment in zebrafish [60]. Normalizing gene expression to total input RNA produced similar results (Additional file 3: Figure S2). We predicted that qRT-PCR results would follow the RNA-sequencing results and assessed and reported significance using onetail p-values.

\section{Behavioral assay}

Fish exposed to a stereoisomer of fluoxetine and control fish were tested in the Novel Tank Diving Test (NTDT) using established protocols [11,29] to assess changes in anxiety-related behaviors. Briefly, fish were placed in a $15.2 \times 27.9 \times 22.5 \times 7.1 \mathrm{~cm}$ (height $\times$ top $\times$ bottom $\times$ width) trapezoidal tank (Aquatic Ecosystems) filled with 1.4 $\mathrm{L}$ of system water. We video-recorded the behavior of the fish for six minutes for later analysis using an animal tracking software package (TopScan Lite, Reston, Virginia, USA). Fish treated with racemic mixture of fluoxetine $(\mathrm{n}=12)$ and control fish $(\mathrm{n}=12)$ were tested for five minutes. All fish were five generations removed from the wild. We report latency to enter the top half of the tank, time spent in top half of the tank and stationary time. Stationary time is measured as the amount of time the fish does not exceed a swimming speed of 0.1 $\mathrm{cm} / \mathrm{sec}$ [29]. For fish that never entered the top half of the tank we set the latency as the length of the trial. All procedures and protocols in this study were approved by the North Carolina State University Institutional Animal Care and Use Committee.

\section{Results and discussion}

\section{Fluoxetine reduces anxiety-related behavior but not} stereospecifically

An anxious state is inferred when an animal is placed in an environment where it is conflicted with seeking out potential benefits with that of potential harm (e.g. approach and avoidance) [2]. The approach-avoidance conflict premise is the basis of many common measures of anxiety-related behavioral assays (e.g. open field test, elevated plus maze, light-dark test) $[2,61]$. In zebrafish one ethologically relevant behavior to potential danger is to swim to the bottom substratum and after the threat has passed, the zebrafish will swim back into the water column. The novel tank diving assay used in this study measures behavioral levels of stress and anxiety-related behaviors in zebrafish by assessing latency to and time spent in the top half of the tank $[11,29]$. In this study wild-derived zebrafish treated with racemic fluoxetine spent significantly more time in $\left(\mathrm{t}=-6.49, \mathrm{p}=2 \times 10^{-6}\right)$ and had a shorter latency to the top half of the tank $\left(t=8.92, p=1.38 \times 10^{-8}\right)$ compared to the controls (Figure 1A). This suggests that fluoxetine treatment reduced stress and anxiety-related behaviors in male zebrafish. Our data are consistent with published anxiolytic effects of fluoxetine in domestiecated zebrafish and rodents $[11,12]$. Fluoxetine has also been documented to alter locomotion [11,12], which could confound interpretations of stress and anxiety levels. In this study we did not observe significant differences in locomotion time (i.e. stationary time $(\mathrm{t}$-stat $=1.29, \mathrm{p}=$ 0.21 ), Figure 1A) suggesting that in our experiment the anxiolytic effect of fluoxetine is not likely to be a consequence of reduced ability or motivation to swim.

While both isomers reduced stress and anxiety-related behaviors, one was not more potent than the other. There were no significant differences in time spent in the top half of the tank between zebrafish treated with $\mathrm{R}$ - or $\mathrm{S}$ - fluoxetine $(\mathrm{t}=1.47, \mathrm{p}=0.16$, Figure $1 \mathrm{~B})$, but

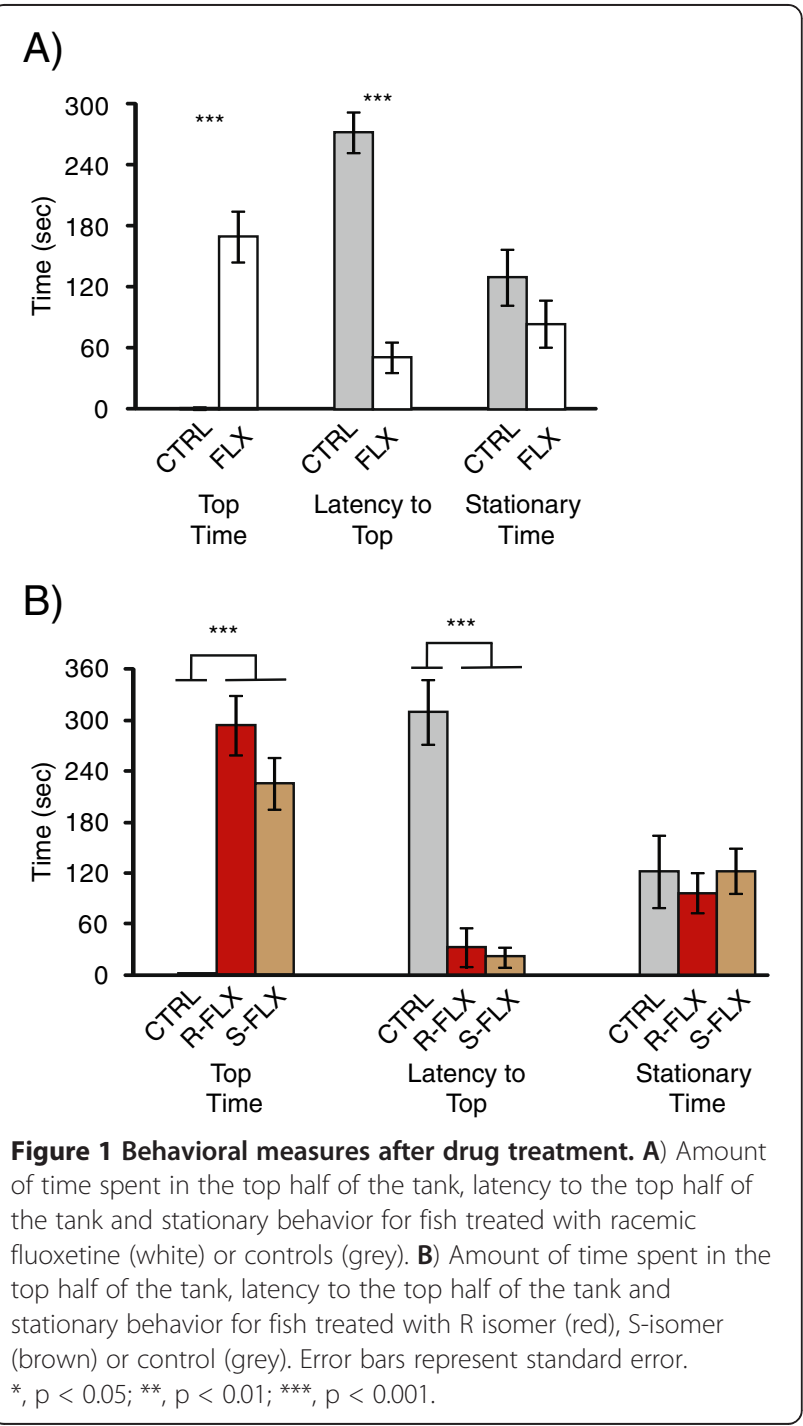


both treatment groups spent significantly more time in the top than controls $\left(\mathrm{F}=30.13, \mathrm{p}=8.31 \times 10^{-8}\right.$, Figure 1B). Relatedly, fish treated with either isomer had a shorter latency to enter the top half of the tank relative to controls $\left(\mathrm{F}=39.32, \mathrm{p}=5.5 \times 10^{-9}\right.$, Figure $\left.1 \mathrm{~B}\right)$ but there were no stereospecific effects $(t=0.39, p=0.7$, Figure 1B). Each fluoxetine isomer had minimal effects on locomotor activity $(\mathrm{F}=0.22, \mathrm{p}=0.8$, Figure $1 \mathrm{~B})$. Our data are consistent with the idea that given both fluoxetine isomers exhibit similar pharmacodynamics in inhibiting the serotonin transporter [6-10], there would be no predicted differences in anxiolytic effects. Fluoxetine, however, increases neurosteroid production (e.g. allopregnanolone) in a stereospecific manner and this has been proposed as an alternative mechanism of action for anxiolytics in mammals [14,62]. Although we did not see any stereospecific anxiolytic effects of fluoxetine at the behavioral level, we have evidence that steroidogenic molecular pathways in the brain are overrepresented with racemic treatment (Table 1 and 2, discussion below). Hence it is possible in zebrafish that some anxiolytic mechanisms of fluoxetine include alteration of both serotonin and neurosteroid levels.

\section{Changes in gene expression consistent with alterations in stress and anxiety levels}

Neuropeptides have modulatory roles in a variety of behaviors including stress and anxiety. RNA-sequencing analysis showed that several neuropeptides associated with stress and anxiety in other studies were differentially regulated with racemic fluoxetine treatment and validated with qRT-PCR (Figure 2). Isotocin (oxtl, RNAsequencing: test statistic $=-3.74, \mathrm{p}=0.014 ; \mathrm{qRT}-\mathrm{PCR}$ : $\mathrm{p}=0.034$ ) and neuropeptide $\mathrm{Y}$ (npy, test statistic $=-5.37$, $\mathrm{p}=1.8 \times 10^{-5}$; qRT-PCR: $\left.\mathrm{p}=0.045\right)$ showed significantly higher expression in fluoxetine treated fish relative to controls (Figure 2A, B). While isotocin is homologous to the mammalian oxytocin, relatively little is known about isotocin's behavioral functions in fishes [63]. In wild-type zebrafish, peripheral isotocin injection decreased the level of fear response to a predator in a dose-dependent manner [64], which suggests an anxiolytic effect. In rodents, pharmacological manipulations, gene expression, and transgenic animal studies have shown increases in oxytocin and NPY levels are associated with reduced anxiety [65-72]. Oxytocin is thought to affect many social behaviors in humans [73] including having anxiolytic effects $[74,75]$. Interestingly, variants of NPY in humans are associated with anxiety susceptibility [76] and zebrafish may be an ideal system to explore this further.

Anxiety-related behavioral displays are often associated with a physiological stress response. The stress response in teleosts has been well-described $[77,78]$ and the molecular mechanisms underlying the cortisol stress response in zebrafish are similar to mammals [33,79]. While we did not measure corticosteroid levels, the first study administering fluoxetine to domesticated zebrafish in the same paradigm used in this study found reduced whole-body cortisol levels compared to controls [11]. At the molecular level, urocortin 3 (ucn3l, part of the corticotrophin-releasing hormone family) and prolactin (prl2) were down-regulated with fluoxetine treatment in both RNA-sequencing (ucn3l: test statistic $=3.99, \mathrm{p}=$ 0.006 ; prl2: test statistic $=5.35, \mathrm{p}=1.98 \times 10^{-5}$; Figure 2C, D) and qRT-PCR analyses (ucn3l and prl2, p < 0.001 , Figure $2 \mathrm{C}, \mathrm{D})$. Urocortin 1-3 interact with the corticotrophin system in the brain by binding to the same receptors and can alter stress and anxiety [80-83]. Specifically, central administration of urocortins has been shown to be anxiogenic in rats [84-88]. The exact role of urocortin 3 in mediating stress and anxiety is not well understood as pharmacological and knock-out studies in rodents produce inconsistent results [89-91]. Prolactin in the brain is often associated with maternal behavior, but it is also associated with stress coping [92-94]. Other teleosts displayed elevated plasma prolactin levels in response to stress $[95,96]$, which is consistent with our results where treatment with an anxiolytic reduced prl2 expression. It should be noted that for the gene expression parts of this study, we did not induce stress prior to brain extraction and this may explain why more genes associated with a stress response were not differentially regulated (Additional file 4: Table S2). Hence the reduction of $u c n 3 l$ and prl2 expression compared to the controls is consistent with the fluoxetine-treated fish having lower basal stress levels.

Neurotransmitter transporters have an important role in maintaining neural activity. The gene coding for the GABA transporter, slc6a11, was significantly downregulated in fluoxetine treated fish with RNA-sequencing (test statistic $=6.06, \mathrm{p}=4.49 \times 10^{-7}$, Figure 3A). Alteration of GABA mediated signaling is one proposed causal mechanism of anxiety and GABA transporter knockout mice exhibit reduced anxiety- and depression-related behaviors [97]. Hence, lower expression of GABA transporter is consistent with the finding that fluoxetine treated fish had reduced stress and anxiety-related behaviors. qRT-PCR validation showed mixed results where normalizing to a housekeeping gene showed significant differences between groups $(\mathrm{p}=0.035$, Figure $3 \mathrm{~A})$ but normalizing to total RNA did not $(\mathrm{t}=1.34, \mathrm{p}=0.096$, Additional file 3: Figure S2). The serotonin transporters (slc6a4a and slc6a4b) showed no differences in expression between groups by RNA-sequencing (slc6a4a: test statistic $=0.957, \mathrm{p}=0.855 ;$ slc6a4b: test statistic $=0.86$, $\mathrm{p}=0.876$; Figure 3B, C) or qRT-PCR (slc6a4a: $\mathrm{p}=$ 0.058 ; slc6a4b: $\mathrm{p}=0.242$; Figure $3 \mathrm{~B}, \mathrm{C}$ ). This is consistent with other studies in teleosts and rodents where 
Table 1 Gene ontology analysis of differentially expressed genes

\begin{tabular}{|c|c|c|c|c|c|}
\hline \multicolumn{3}{|c|}{ Gene ontology } & \multicolumn{3}{|c|}{ FDR corrected $p$-value } \\
\hline Category & Term & ID & $\begin{array}{c}\text { DEG } \\
(n=411)\end{array}$ & $\begin{array}{l}\text { Up-regulated } \\
(n=167)\end{array}$ & $\begin{array}{c}\text { Down-regulated } \\
(n=244)\end{array}$ \\
\hline $\mathrm{BP}$ & lipid metabolic process & GO:0006629 & $1.62 \mathrm{E}-03$ & & $6.01 \mathrm{E}-07$ \\
\hline $\mathrm{BP}$ & lipid biosynthetic process & GO:0008610 & $8.22 \mathrm{E}-03$ & & $5.75 \mathrm{E}-05$ \\
\hline $\mathrm{BP}$ & fatty acid metabolic process & GO:0006631 & 8.77E-03 & & $2.21 \mathrm{E}-04$ \\
\hline $\mathrm{BP}$ & very long-chain fatty acid metabolic process & GO:0000038 & $7.78 \mathrm{E}-03$ & & $1.99 \mathrm{E}-03$ \\
\hline $\mathrm{BP}$ & fatty acid biosynthetic process & GO:0006633 & 1.09E-02 & & 4.35E-04 \\
\hline $\mathrm{BP}$ & very long-chain fatty acid biosynthetic process & GO:0042761 & 7.78E-03 & & 1.99E-03 \\
\hline $\mathrm{BP}$ & small molecule metabolic process & GO:0044281 & $1.06 \mathrm{E}-02$ & & \\
\hline $\mathrm{BP}$ & organic acid metabolic process & GO:0006082 & $1.56 \mathrm{E}-04$ & $1.83 \mathrm{E}-02$ & \\
\hline $\mathrm{BP}$ & oxoacid metabolic process & GO:0043436 & $1.56 \mathrm{E}-04$ & $1.83 \mathrm{E}-02$ & \\
\hline $\mathrm{BP}$ & carboxylic acid metabolic process & GO:0019752 & $5.22 \mathrm{E}-04$ & $1.43 \mathrm{E}-02$ & \\
\hline $\mathrm{BP}$ & single-organism biosynthetic process & GO:0044711 & $2.24 \mathrm{E}-03$ & & \\
\hline $\mathrm{BP}$ & small molecule biosynthetic process & GO:0044283 & $1.93 \mathrm{E}-03$ & & \\
\hline $\mathrm{BP}$ & organic acid biosynthetic process & GO:0016053 & $2.86 \mathrm{E}-04$ & & \\
\hline $\mathrm{BP}$ & carboxylic acid biosynthetic process & GO:0046394 & $2.86 \mathrm{E}-04$ & & \\
\hline $\mathrm{BP}$ & L-serine metabolic process & GO:0006563 & $2.66 \mathrm{E}-02$ & $2.66 \mathrm{E}-03$ & \\
\hline $\mathrm{BP}$ & organonitrogen compound metabolic process & GO:1901564 & & 4.70E-02 & \\
\hline $\mathrm{BP}$ & organonitrogen compound biosynthetic process & GO:1901566 & & $1.88 \mathrm{E}-02$ & \\
\hline $\mathrm{BP}$ & cellular amino acid metabolic process & GO:0006520 & & $2.27 \mathrm{E}-03$ & \\
\hline $\mathrm{BP}$ & cellular amino acid biosynthetic process & GO:0008652 & & $2.54 \mathrm{E}-02$ & \\
\hline $\mathrm{BP}$ & alpha-amino acid biosynthetic process & GO:1901607 & & $1.66 \mathrm{E}-02$ & \\
\hline $\mathrm{BP}$ & serine family amino acid biosynthetic process & GO:0009070 & & $6.35 \mathrm{E}-03$ & \\
\hline $\mathrm{BP}$ & response to virus & GO:0009615 & & 3.05E-03 & \\
\hline $\mathrm{BP}$ & monocarboxylic acid metabolic process & GO:0032787 & & & 2.07E-03 \\
\hline $\mathrm{BP}$ & monocarboxylic acid biosynthetic process & GO:0072330 & & & $2.60 \mathrm{E}-03$ \\
\hline $\mathrm{BP}$ & steroid metabolic process & GO:0008202 & & & 4.99E-02 \\
\hline $\mathrm{BP}$ & cellular lipid metabolic process & GO:0044255 & & & $4.82 \mathrm{E}-03$ \\
\hline $\mathrm{BP}$ & sterol metabolic process & GO:0016125 & & & $1.21 \mathrm{E}-02$ \\
\hline MF & phosphorylase activity & GO:0004645 & 4.24E-02 & & 7.31E-03 \\
\hline MF & glycogen phosphorylase activity & GO:0008184 & $1.72 \mathrm{E}-02$ & & 2.95E-03 \\
\hline MF & cofactor binding & GO:0048037 & $3.24 \mathrm{E}-02$ & & \\
\hline MF & catalytic activity & GO:0003824 & $3.19 E-02$ & & \\
\hline MF & oxidoreductase activity & GO:0016491 & $2.96 \mathrm{E}-03$ & & 1.43E-03 \\
\hline MF & $\begin{array}{l}\text { oxidoreductase activity, acting on } \mathrm{CH}-\mathrm{OH} \text { group of } \\
\text { donors }\end{array}$ & GO:0016614 & & & $8.66 \mathrm{E}-03$ \\
\hline MF & transferase activity, transferring acyl groups & GO:0016746 & & & $9.02 \mathrm{E}-03$ \\
\hline MF & $\begin{array}{c}\text { oxidoreductase activity, acting on paired donors, with } \\
\text { incorporation or reduction of molecular oxygen, NADH } \\
\text { or NADPH as one donor, and incorporation of one } \\
\text { atom of oxygen }\end{array}$ & GO:0016709 & & & 2.47E-02 \\
\hline
\end{tabular}

BP Biological Process, MF Molecular Function, DEG all differentially expressed genes. Blank cells indicate $p>0.05$.

chronic fluoxetine treatment altered expression of genes other than the serotonin transporter [42,98-101]. SSRIs bind to serotonin transporters to inhibit their function, however, SSRIs may not regulate the expression of the transporter. Although several microarray studies focusing on a specific brain region did not show significant differences in expression of the serotonin transporter gene with fluoxetine treatment [98-101], we cannot rule out brain 
Table 2 KEGG pathway analysis of differentially expressed genes

\begin{tabular}{ll}
\hline KEGG Pathway & $\begin{array}{l}\text { FDR corrected } \\
\text { p-value }\end{array}$ \\
\hline Fatty acid elongation & $2.21 \mathrm{E}-02$ \\
Metabolic pathways & $5.11 \mathrm{E}-04$ \\
Arachidonic acid metabolism & $1.98 \mathrm{E}-03$ \\
Synthesis and degradation of ketone bodies & $1.08 \mathrm{E}-02$ \\
Terpenoid backbone biosynthesis & $4.36 \mathrm{E}-03$ \\
Glycine, serine and threonine metabolism & $2.77 \mathrm{E}-02$ \\
Metabolism of xenobiotics by cytochrome P450 & $6.78 \mathrm{E}-03$ \\
Steroid biosynthesis & $1.96 \mathrm{E}-09$ \\
Steroid hormone biosynthesis & $1.27 \mathrm{E}-03$
\end{tabular}

region specific regulation in zebrafish. Two genes (isg15, $n r b f 2$ ) showed greater than two fold differences in expression between groups in RNA-sequencing (Figure 3D, E, Additional file 4: Table S2) but were not validated by qPCR (isg15: $\mathrm{p}=0.1 ;$ nrbf2: $\mathrm{p}=0.072$ ). The housekeeping gene, elongation factor 1-alpha (ef1a) showed no significant difference between groups in either RNA-sequencing (test statistic $=0.258, \mathrm{p}=0.976$, Figure $3 \mathrm{~F}$ ) or qRT-PCR (Additional file 3: Figure S2). Overall, $80 \%$ of the genes we examined by qRT-PCR showed consistent expression patterns as RNA-sequencing, which is a rate consistent with other transcriptome studies $[102,103]$. There was a trend for a positive correlation between RNA-sequencing and qRT-PCR expression levels across all genes $(\mathrm{n}=10, \mathrm{r}=$ $0.49, \mathrm{p}=0.072$ ). However, when excluding genes (isg15, nrbf2) that did not show consistent expression patterns between RNA-sequencing and qRT-PCR, there was a significant positive correlation $(\mathrm{n}=8, \mathrm{r}=0.88, \mathrm{p}=0.002)$.

\section{Identification of global transcriptome changes and related pathways}

Of the 26,585 protein-coding genes analyzed, 411 were differentially regulated with racemic fluoxetine treatment (Figure 4, Additional file 4: Table S2). In racemic fluoxetine treated fish, 167 and 244 genes were up- and downregulated, respectively. Gene ontology (GO) analysis of all differentially expressed genes reveal that terms related to lipid ( $\mathrm{p}=0.001)$ and small molecule metabolism $(\mathrm{p}=0.01)$ were significantly over-enriched (Table 1$)$. Interestingly when we accounted for direction of

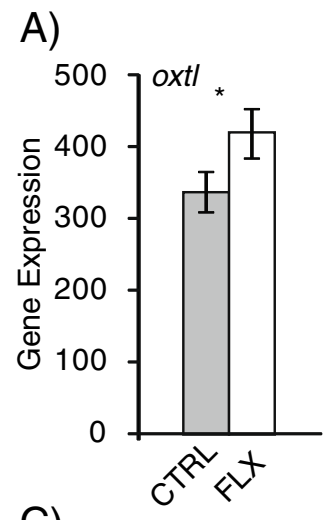

C)

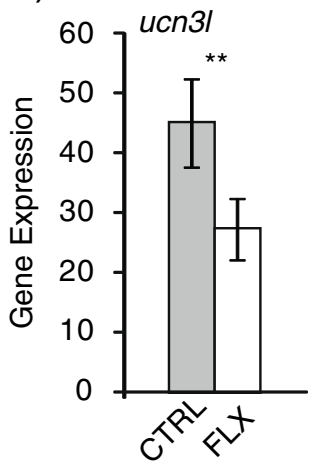

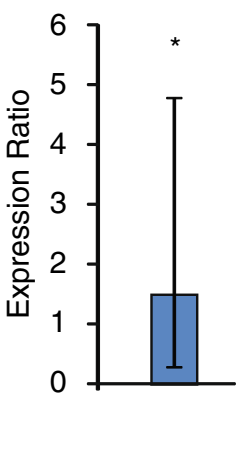

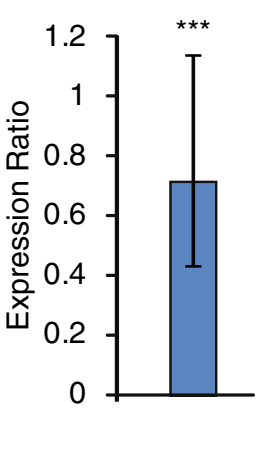

B)
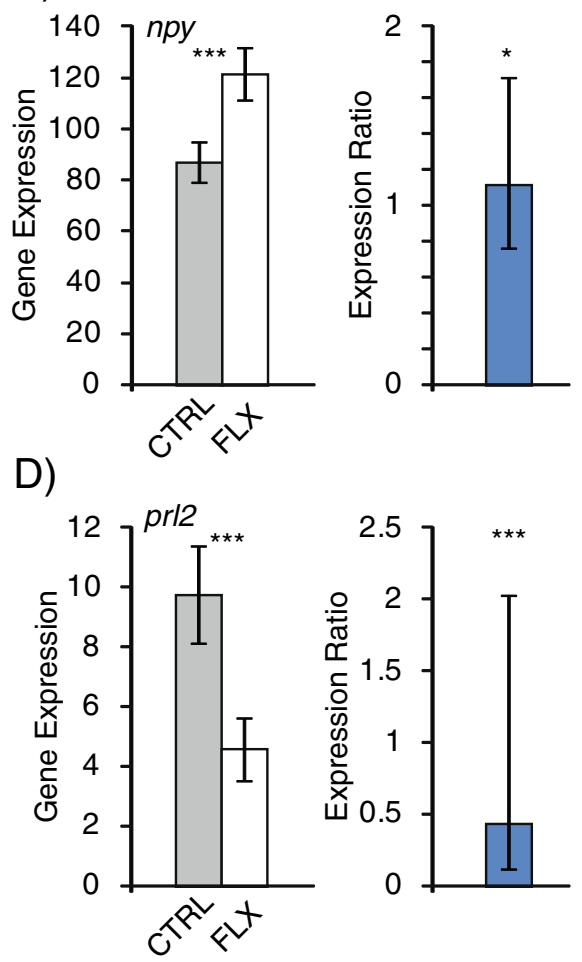

Figure 2 RNA-sequencing and qRT-PCR expression of select genes with racemic fluoxetine treatment. Gene expression of (A) isotocin, (B) neuropeptide Y, (C) urocortin 3, and (D) prolactin. In each panel left and right graphs represent quantification from RNA-sequencing (fragments per kilobase per million reads, FPKM) and GRT-PCR (expression ratio: gene expression in fluoxetine treatment / control), respectively. qRT-PCR gene expression was normalized to a housekeeping gene. Grey and white bars represent control and fluoxetine treatment, respectively. Error bars represent 95\% confidence intervals. ${ }^{*}, \mathrm{p}<0.05$; $^{* *}, \mathrm{p}<0.01$; ${ }^{* *}, \mathrm{p}<0.001$. 


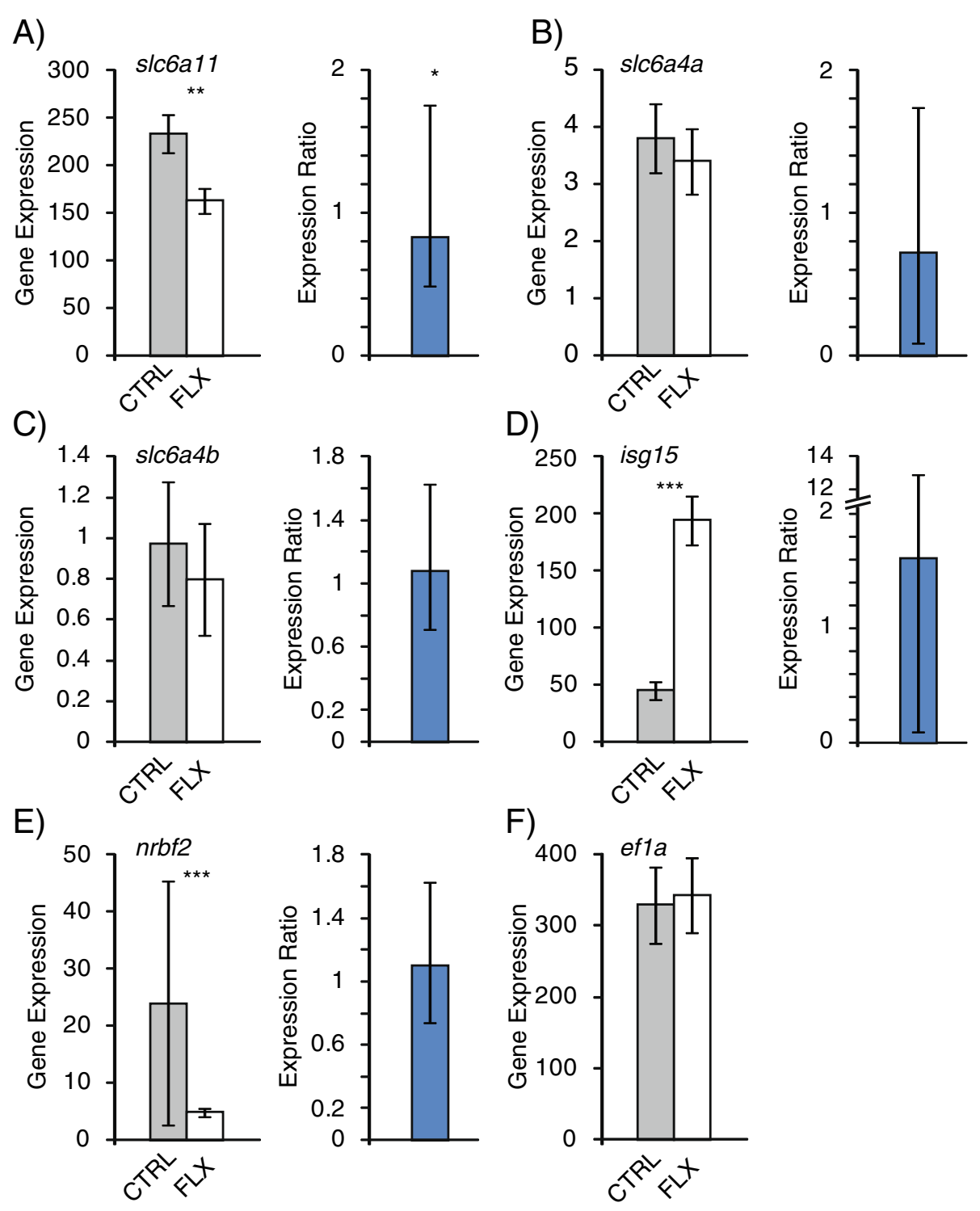

Figure 3 RNA-sequencing and qRT-PCR expression of select genes with racemic fluoxetine treatment. Gene expression of (A) GABA transporter, (B) serotonin transporter A, (C) serotonin transporter B, (D) ISG15 ubiquitin-like modifier, (E) nuclear receptor binding factor 2, and (F) elongation factor 1-alpha. In each panel left and right graphs represent quantification from RNA-sequencing (fragments per kilobase per million reads, FPKM) and qRT-PCR (expression ratio: gene expression in fluoxetine treatment / control), respectively. gRT-PCR gene expression was normalized to a housekeeping gene. Grey and white bars represent control and fluoxetine treatment, respectively. Error bars represent $95 \%$ confidence intervals. ${ }^{*}, \mathrm{p}<0.05{ }^{* *}, \mathrm{p}<0.01 ;{ }^{* *}, \mathrm{p}<0.001$.

expression in the GO analysis, amino acid and lipid metabolic processes were up-regulated and downregulated, respectively, with fluoxetine treatment (Table 1). These data suggest that male zebrafish treated with fluoxetine (i.e., reduced anxiety and stress levels) may be shifting macromolecule resources from energy (e.g. lipid) to enzymatic (e.g. amino acid) processes in the brain. It is well known that individuals will change foraging habits in the presence of predators [104,105] and it is plausible that less anxious zebrafish seek out foods higher in protein content. While we fed the fluoxetine-treated and control groups ad libitum future studies should assess for differences in food consumption or diet preference. An equally likely hypothesis is that individuals with higher stress and anxiety levels have disrupted neurosteroid levels - possibly due to altered precursor activity. Of note, fish used in this study were selectively bred to exhibit high levels of stress and anxiety behaviors and hence control fish are presumed to have high levels of stress and anxiety [29]. Highly stressed and anxious (e.g., control) fish have upregulated lipid and steroid metabolism (Table 1) that 


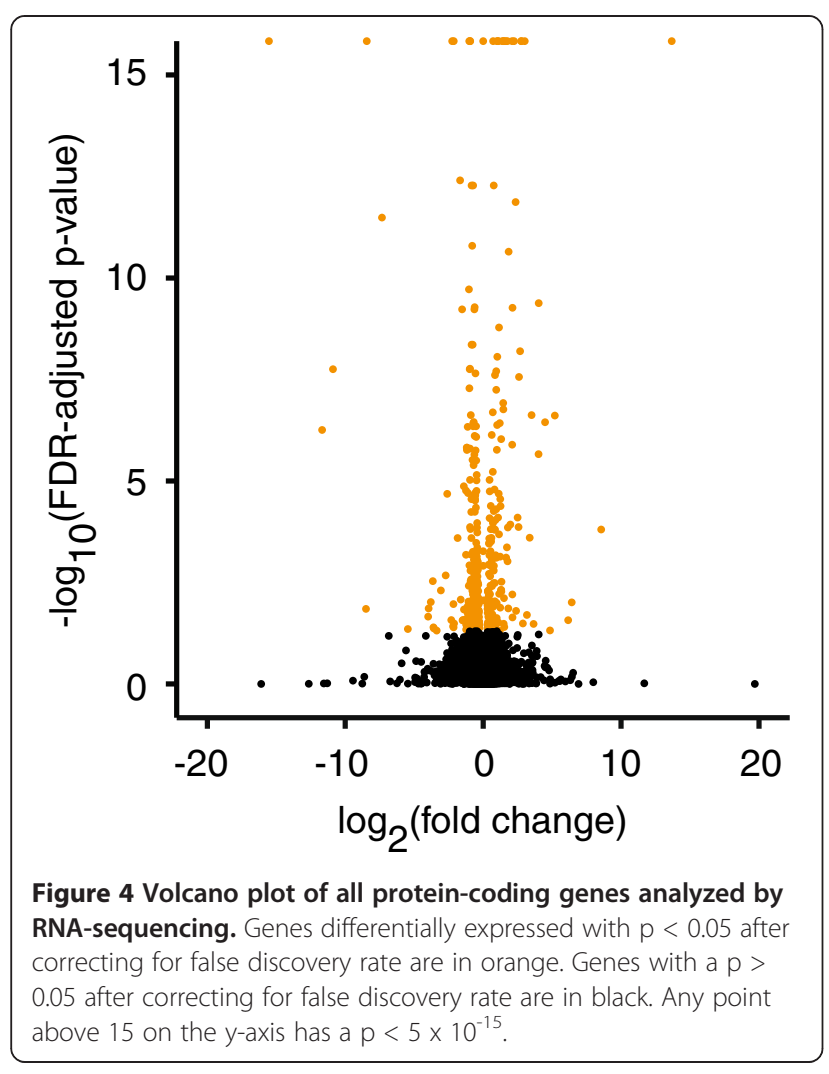

may lead to altered neurosteroid production (via precursor availability). We acknowledge that transcriptome wide patterns are challenging to interpret and in this study we can only speculate on the precise roles of lipid and amino acid metabolism in stress and anxiety. It is also possible that by utilizing the whole brain, we may not be able to detect some pathways that are differentially expressed in specific regions. It should be noted, however, that whole-brain transcriptome studies still provide important insights into the molecular mechanisms of sex differences and a variety of social behaviors [56,106-114]. Future studies should use transgenic zebrafish or pharmacologically alter expression levels to better characterize the role of a gene. Complementary studies could also assess localized differential expression patterns of "candidate" genes across the brain via neurohistochemical techniques [115-117] to assist in identifying candidate brain regions for transcriptomic analyses. Alternatively, using zebrafish with naturally high and low stress and anxiety-related behavioral levels (e.g., HSB, LSB [29]) will provide an opportunity to test for similar sorts of transcriptome changes in a nonpharmacological context and is currently underway in our laboratory.

Using an alternative database to analyze global transcriptome changes that has associations with pathways,
Kyoto Encyclopedia of Genes and Genomes (KEGG $[118,119])$, resulted in largely similar over-represented pathways as GO analysis (Table 2). Amino acid pathways (glycine, serine, and threonine, $\mathrm{p}=5.11 \times 10^{-4}$ ) and lipid related pathways (fatty acid elongation, $p=0.022$ ) were over-represented (Table 2). Notably, steroid ( $\mathrm{p}=1.96 \times$ $\left.10^{-9}\right)$ and steroid hormone $(\mathrm{p}=0.001)$ biosynthesis pathways were also over-represented (Table 2). While we did not measure steroid levels in this study, in male goldfish treated with fluoxetine, there was an increase in estradiol, decrease in testosterone, and no changes in luteinizing or growth hormone serum levels but how these changes relate to anxiety-related behaviors was not discussed [120]. Neurosteroids (e.g. allopregnanolone) are implicated as potential mediators of anxiety in mammals [13-15,18,121]. Fluoxetine can increase neurosteroid content and Sfluoxetine increases allopregnanolone levels more effectively than the $\mathrm{R}$ isomer [13,14,21]. Allopregnanolone reduces anxiety in rodents and has a similar efficacy as fluoxetine [122-125]. As we see reduction in anxietyrelated behaviors (Figure 1) and over-representation of steroid hormone pathways (Table 2) in the brain with fluoxetine treatment, it is possible that the anxiolytic effects seen in this study are due to changes in neurosteroid content.

Few studies have examined transcriptome level changes in gene expression with fluoxetine treatment in teleosts. One study has examined the effects of fluoxetine treatment on differential gene expression in whole body larval zebrafish through microarrays [42]. Of genes we found differentially expressed in adult male wholebrain zebrafish, only three of these genes $(f k b p 5$, itm $2 c b$, and an unannotated gene) were also differentially expressed in larval zebrafish [42]. Fluoxetine is known to have age-dependent effects in mammals and it is possible that we are observing molecular evidence of this in zebrafish [126-128]. It should be noted though, that changes in membrane protein activity and/or composition (e.g. $f k b p 5$, itm $2 c b$ ) may be a common mechanism of fluoxetine action across the lifecycle. Interestingly, in a microarray study identifying hypothalamic differential gene expression in female goldfish treated with fluoxetine, we observed only three genes (trib3,oxtl, $m b p b)$ that were similarly differentially regulated in our study. It is possible that this minimal amount of overlap between lists of genes differentially regulated is due to sex or regional specificity. Hypothalamic isotocin levels decreased with fluoxetine treatment in female goldfish [98] but showed no expression differences in male telencephalon [120]. It should be noted that neither of the studies utilizing fluoxetine-treated goldfish $[98,120]$ or larval zebrafish [42] measured anxiety-related behavior. Surprisingly, the lack of a large overlap of differentially expressed genes with fluoxetine treatment was also found 
between mice and rats with genomic analyses [99-101]. While there may be species- and brain region-specific effects of fluoxetine, uncovering potential universal mechanisms of action of fluoxetine will need to utilize a more comprehensive comparative approach.

\section{Conclusions}

In this study we present data from both behavioral and molecular levels showing that fluoxetine alters stress and anxiety-related behaviors in wild-derived male zebrafish. Racemic and stereoisomers of fluoxetine reduce anxietyrelated behaviors as indicated by drug treated fish spending more time in the top half of the tank. There were no stereoisomer effects on behavior but these effects were not tested at the molecular levels where it is possible that GABAergic and serotonergic activity were altered. In the small sampling of "candidate" neuropeptides (npy, oxtl, prl2, ucn3l) linked to stress and anxiety in the literature, our gene expression results were consistent with fluoxetine-induced changes at the molecular level in other model systems. Larger scale analyses reveal that lipid and amino acid metabolic processes and steroid biosynthesis are disproportionately influenced. Changes in lipid, amino acid and neurosteroid utilization in the brain may be characteristic of fluoxetine treatment and, by extension, stress and anxiety.

\section{Additional files}

Additional file 1: Figure S1. Fluoxetine dose-response curve. Time spent on the top half of the tank (y-axis) for fish treated with $0,11,33$, and $100 \mu \mathrm{g} / \mathrm{L}$ racemic fluoxetine ( $\mathrm{x}$-axis). $\mathrm{N}=6$ at each concentration.

Additional file 2: Table S1. qRT-PCR primer characteristics.

Additional file 3: Figure S2. QRT-PCR validation of expression of select genes with racemic fluoxetine treatment. Genes examined are (A) isotocin, (B) neuropeptide $Y,(C)$ urocortin 3, (D), prolactin, (E) GABA transporter, (F) serotonin transporter A, (G) serotonin transporter B, (H) ISG15 ubiquitin-like modifier, (I) nuclear receptor binding factor 2, and (J) elongation factor 1-alpha. Gene expression values are normalized to total RNA input. Error bars represent standard error. *, $p<0.05$; **; ***, $p<$ $0.001 ;+$, data is consistent with RNA-sequencing results.

Additional file 4: Table S2. Significant differentially expressed genes with fluoxetine treatment after correcting for false discovery rate.

\section{Competing interests}

The authors declare that they have no competing interests.

\section{Authors' contributions}

RYW carried out the transcriptome and GRT-PCR studies, participated in the behavioral experiments, analyzed and performed statistical analyses on all data, participated in the design of the experiment, and drafted the manuscript. SEO carried out and quantified the behavioral experiments for the stereoisomers of fluoxetine. JG conceived the study, participated in the design of the experiment, interpretation of the data, and helped to draft the manuscript. All authors read and approved the final manuscript.

\section{Acknowledgements}

We would like to thank Brad Ring and John Davis for assistance with fish husbandry. We are grateful to Noffisat Oki, Melissa Slane, Xiaoyang Yao, Yijun Zhang, Katie Robertson, and Mary Ramsey for helpful discussions and technical assistance. This study received support from the National Institutes of Health (1R21MH080500) to J.G., the NIH-supported Initative for Maximizing Student Diversity Program at NCSU and the Park Foundation to S.E.O.

\section{Author details}

'Department of Biology, North Carolina State University, Box 7617, Raleigh, NC 27695-7617, USA. 'WM Keck Center for Behavioral Biology, North Carolina State University, Box 7617, Raleigh, NC 27695-7617, USA.

Received: 22 January 2013 Accepted: 16 May 2013

Published: 24 May 2013

\section{References}

1. American Psychiatric Association: Diagnostic criteria from DSM-IV-TR. Washington, D.C: American Psychiatric Association; 2000.

2. Cryan JF, Sweeney FF: The age of anxiety: role of animal models of anxiolytic action in drug discovery. Br J Pharmacol 2011, 164:1129-1161.

3. Durant C, Christmas D, Nutt D: The pharmacology of anxiety. Curr Top Behav Neurosci 2010, 2:303-330.

4. Jacobson LH, Cryan JF: Genetic approaches to modeling anxiety in animals. Curr Top Behav Neurosci 2010, 2:161-201.

5. Westenberg HG: Recent advances in understanding and treating social anxiety disorder. CNS Spectr 2009, 14:24-33.

6. Pinna G, Costa E, Guidotti A: Fluoxetine and norfluoxetine stereospecifically facilitate pentobarbital sedation by increasing neurosteroids. Proc Natl Acad Sci USA 2004, 101:6222-6225.

7. Wong DT, Bymaster FP, Engleman EA: Prozac (fluoxetine, lilly 110140), the first selective serotonin uptake inhibitor and an antidepressant drug: Twenty years since its first publication. Life Sci 1995, 57:411-441.

8. Wong DT, Bymaster FP, Reid LR, Fuller RW, Perry KW: Inhibition of serotonin uptake by optical isomers of fluoxetine. Drug Dev Res 1985, 6:397-403.

9. Koch S, Perry KW, Nelson DL, Conway RG, Threlkeld PG, Bymaster FP: Rfluoxetine increases extracellular DA, NE, as well as 5-HT in rat prefrontal cortex and hypothalamus: an in vivo microdialysis and receptor binding study. Neuropsychopharmacology 2002, 27:949-959.

10. Robertson DW, Krushinski JH, Fuller RW, Leander JD: Absolute configurations and pharmacological activities of the optical isomers of fluoxetine, a selective serotonin-uptake inhibitor. J Med Chem 1988, 31:1412-1417.

11. Egan RJ, Bergner CL, Hart PC, Cachat JM, Canavello PR, Elegante MF, Elkhayat SI, Bartels BK, Tien AK, Tien DH, et al: Understanding behavioral and physiological phenotypes of stress and anxiety in zebrafish. Behav Brain Res 2009, 205:38-44.

12. Dulawa SC, Holick KA, Gundersen B, Hen R: Effects of Chronic Fluoxetine in Animal Models of Anxiety and Depression. Neuropsychopharmacology 2004, 29:1321-1330.

13. Pinna $G$, Costa $E$, Guidotti A: SSRIs act as selective brain steroidogenic stimulants (SBSSs) at low doses that are inactive on 5-HT reuptake. Curr Opin Pharmacol 2009, 9:24-30.

14. Pinna G, Costa E, Guidotti A: Fluoxetine and norfluoxetine stereospecifically and selectively increase brain neurosteroid content at doses that are inactive on 5-HT reuptake. Psychopharmacology (Berl) 2006, 186:362-372.

15. Longone P, Di Michele F, D'Agati E, Romeo E, Pasini A, Rupprecht R: Neurosteroids as neuromodulators in the treatment of anxiety disorders. Front Endocrinol (Lausanne) 2011, 2:55.

16. Barbaccia ML: Neurosteroidogenesis: relevance to neurosteroid actions in brain and modulation by psychotropic drugs. Crit Rev Neurobiol 2004, 16:67-74.

17. Reddy DS, O'Malley BW, Rogawski MA: Anxiolytic activity of progesterone in progesterone receptor knockout mice. Neuropharmacology 2005, 48:14-24.

18. Pinna G, Rasmusson AM: Up-regulation of neurosteroid biosynthesis as a pharmacological strategy to improve behavioural deficits in a putative mouse model of post-traumatic stress disorder. J Neuroendocrinol 2012, 24:102-116.

19. Schule C, Eser D, Baghai TC, Nothdurfter C, Kessler JS, Rupprecht R: Neuroactive steroids in affective disorders: target for novel antidepressant or anxiolytic drugs? Neuroscience 2011, 191:55-77. 
20. Guidotti A, Dong E, Matsumoto K, Pinna G, Rasmusson AM, Costa E: The socially-isolated mouse: a model to study the putative role of

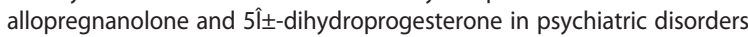
Brain Res Rev 2001, 37:110-115.

21. Pinna G, Dong E, Matsumoto $K$, Costa E, Guidotti A: In socially isolated mice, the reversal of brain allopregnanolone down-regulation mediates the anti-aggressive action of fluoxetine. Proc Natl Acad Sci USA 2003, 100:2035-2040.

22. Jain NS, Hirani K, Chopde CT: Reversal of caffeine-induced anxiety by neurosteroid 3-alpha-hydroxy-5-alpha-pregnane-20-one in rats. Neuropharmacology 2005, 48:627-638.

23. Bitran D, Foley M, Audette D, Leslie N, Frye CA: Activation of peripheral mitochondrial benzodiazepine receptors in the hippocampus stimulate allopregnanolone synthesis and produces anxiolytic-like effects in the rat. Psychopharmacology (Berl) 2000, 151:64-71.

24. Landgraf R: Neuropeptides in anxiety modulation. Handb Exp Pharmacol 2005, 169:335-369.

25. Semsar K, Perreault HA, Godwin J: Fluoxetine-treated male wrasses exhibit low AVT expression. Brain Res 2004, 1029:141-147.

26. Cryan JF, Holmes A: The ascent of mouse: advances in modelling human depression and anxiety. Nat Rev Drug Discov 2005, 4:775-790.

27. Overli O, Pottinger TG, Carrick TR, Overli E, Winberg S: Differences in behaviour between rainbow trout selected for high- and low-stress responsiveness. J Exp Biol 2002, 205:391-395.

28. Landgraf $\mathrm{R}$, Wigger $\mathrm{A}$ : High vs low anxiety-related behavior rats: an animal model of extremes in trait anxiety. Behav Genet 2002, 32:301-314

29. Wong RY, Perrin F, Oxendine SE, Kezios ZD, Sawyer S, Zhou L, Dereje S, Godwin J: Comparing behavioral responses across multiple assays of stress and anxiety in zebrafish (Danio rerio). Behaviour 2012, 149:1205-1240.

30. Maximino C, de Brito TM, da Silva Batista AW, Herculano AM, Morato S, Gouveia A Jr: Measuring anxiety in zebrafish: a critical review. Behav Brain Res 2010, 214:157-171.

31. Stewart A, Gaikwad S, Kyzar E, Green J, Roth A, Kalueff AV: Modeling anxiety using adult zebrafish: a conceptual review. Neuropharmacology 2012, 62:135-143.

32. Clark KJ, Boczek NJ, Ekker SC: Stressing zebrafish for behavioral genetics. Rev Neurosci 2011, 22:49-62.

33. Steenbergen PJ, Richardson MK, Champagne DL: The use of the zebrafish model in stress research. Prog Neuropsychopharmacol Biol Psychiatry 2011, 35:1432-1451.

34. Champagne DL, Hoefnagels CC, de Kloet RE, Richardson MK: Translating rodent behavioral repertoire to zebrafish (Danio rerio): relevance for stress research. Behav Brain Res 2010, 214:332-342.

35. Howe K, Clark MD, Torroja CF, Torrance J, Berthelot C, Muffato M, Collins JE, Humphray S, McLaren K, Matthews L, et al: The zebrafish reference genome sequence and its relationship to the human genome. Nature 2013, 496:498-503.

36. Griebel G, Belzung C, Perrault G, Sanger DJ: Differences in anxiety-related behaviours and in sensitivity to diazepam in inbred and outbred strains of mice. Psychopharmacology (Berl) 2000, 148:164-170.

37. Miller BH, Schultz LE, Gulati A, Su Al, Pletcher MT: Phenotypic Characterization of a Genetically Diverse Panel of Mice for Behavioral Despair and Anxiety. PLoS One 2010, 5:e14458.

38. Panula $P$, Chen YC, Priyadarshini M, Kudo H, Semenova S, Sundvik M, Sallinen $\mathrm{V}$ : The comparative neuroanatomy and neurochemistry of zebrafish CNS systems of relevance to human neuropsychiatric diseases. Neurobiol Dis 2010, 40:46-57.

39. Lillesaar C: The serotonergic system in fish. J Chem Neuroanat 2011 41:294-308

40. Wang $Y$, Takai $R$, Yoshioka $H$, Shirabe $K$ : Characterization and expression of serotonin transporter genes in zebrafish. Tohoku J Exp Med 2006, 208:267-274.

41. Gould GG, Brooks BW: Frazer A: [(3)H] citalopram binding to serotonin transporter sites in minnow brains. Basic Clin Pharmacol Toxicol 2007 101:203-210.

42. Park JW, Heah TP, Gouffon JS, Henry TB, Sayler GS: Global gene expression in larval zebrafish (Danio rerio) exposed to selective serotonin reuptake inhibitors (fluoxetine and sertraline) reveals unique expression profiles and potential biomarkers of exposure. Environ Pollut 2012, 167:163-170.

43. Zon LI, Peterson RT: In vivo drug discovery in the zebrafish. Nat Rev Drug Discov 2005, 4:35-44
44. Rihel J, Schier AF: Behavioral screening for neuroactive drugs in zebrafish. Dev Neurobio/ 2012, 72:373-385.

45. Grunwald DJ, Eisen JS: Headwaters of the zebrafish - emergence of a new model vertebrate. Nat Rev Genet 2002, 3:717-724

46. Brooks BW, Chambliss CK, Stanley JK, Ramirez A, Banks KE, Johnson RD, Lewis RJ: Determination of select antidepressants in fish from an effluent-dominated stream. Environ Toxicol Chem 2005, 24:464-469.

47. Gaworecki KM, Klaine SJ: Behavioral and biochemical responses of hybrid striped bass during and after fluoxetine exposure. Aquat Toxicol 2008, 88:207-213

48. Paterson G, Metcalfe CD: Uptake and depuration of the anti-depressant fluoxetine by the Japanese medaka (Oryzias latipes). Chemosphere 2008 74:125-130

49. Auer PL, Doerge RW: Statistical design and analysis of RNA sequencing data. Genetics 2010, 185:405-416.

50. Wu TD, Nacu S: Fast and SNP-tolerant detection of complex variants and splicing in short reads. Bioinformatics 2010, 26:873-881.

51. Trapnell C, Roberts A, Goff L, Pertea G, Kim D, Kelley DR, Pimentel H, Salzberg SL, Rinn JL, Pachter L: Differential gene and transcript expression analysis of RNA-seq experiments with TopHat and Cufflinks. Nat Protocols 2012, 7:562-578.

52. Trapnell C, Williams BA, Pertea G, Mortazavi A, Kwan G, van Baren MJ, Salzberg SL, Wold BJ, Pachter L: Transcript assembly and quantification by RNA-Seq reveals unannotated transcripts and isoform switching during cell differentiation. Nat Biotech 2010, 28:511-515.

53. Trapnell C, Hendrickson DG, Sauvageau M, Goff L, Rinn JL, Pachter L: Differential analysis of gene regulation at transcript resolution with RNAseq. Nat Biotech 2013, 31:46-53.

54. Reimand J, Arak T, Vilo J g: Profiler-a web server for functional interpretation of gene lists (2011 update). Nucleic Acids Res 2011, 39:W307-W315.

55. Reimand J, Kull M, Peterson H, Hansen J, Vilo J g: Profiler-a web-based toolset for functional profiling of gene lists from large-scale experiments. Nucleic Acids Res 2007, 35:W193-W200.

56. Cummings ME, Larkins-Ford J, Reilly CR, Wong RY, Ramsey M, Hofmann HA: Sexual and social stimuli elicit rapid and contrasting genomic responses. Proc Biol Sci 2008, 275:393-402.

57. Lynch KS, Ramsey ME, Cummings ME: The mate choice brain: comparing gene profiles between female choice and male coercive poeciliids. Genes Brain Behav 2012, 11:222-229.

58. Ramsey ME, Maginnis TL, Wong RY, Brock C, Cummings ME: Identifying context-specific gene profiles of social, reproductive, and mate preference behavior in a fish species with female mate choice. Front Neurosci 2012, 6:62

59. Pfaffl MW, Horgan GW, Dempfle L: Relative expression software tool (REST) for group-wise comparison and statistical analysis of relative expression results in real-time PCR. Nucleic Acids Res 2002, 30:e36.

60. McCurley AT, Callard GV: Characterization of housekeeping genes in zebrafish: male-female differences and effects of tissue type, developmental stage and chemical treatment. BMC Mol Biol 2008, 9:102.

61. Sousa N, Almeida OF, Wotjak CT: A hitchhiker's guide to behavioral analysis in laboratory rodents. Genes Brain Behav 2006, 5(Suppl 2):5-24.

62. Uzunova V, Sheline Y, Davis JM, Rasmusson A, Uzunov DP, Costa E, Guidotti $A$ : Increase in the cerebrospinal fluid content of neurosteroids in patients with unipolar major depression who are receiving fluoxetine or fluvoxamine. Proc Natl Acad Sci USA 1998, 95:3239-3244

63. Godwin J, Thompson R: Nonapeptides and social behavior in fishes. Horm Behav 2012, 61:230-238.

64. Braida D, Donzelli A, Martucci R, Capurro V, Busnelli M, Chini B, Sala M: Neurohypophyseal hormones manipulation modulate social and anxietyrelated behavior in zebrafish. Psychopharmacology (Berl) 2012, 220:319-330.

65. Thorsell A: Central neuropeptide $Y$ in anxiety- and stress-related behavior and in ethanol intake. Ann N Y Acad Sci 2008, 1148:136-140.

66. Neumann ID, Landgraf R: Balance of brain oxytocin and vasopressin: implications for anxiety, depression, and social behaviors. Trends Neurosci 2012, 35:649-659.

67. Karlsson RM, Holmes A, Heilig M, Crawley JN: Anxiolytic-like actions of centrally-administered neuropeptide $\mathrm{Y}$, but not galanin, in $\mathrm{C} 57 \mathrm{BL} / 6 \mathrm{~J}$ mice. Pharmacol Biochem Behav 2005, 80:427-436.

68. Slattery DA, Neumann ID: Chronic icv oxytocin attenuates the pathological high anxiety state of selectively bred Wistar rats. Neuropharmacology 2010, 58:56-61. 
69. Kask A, Harro J, von Horsten S, Redrobe JP, Dumont Y, Quirion R: The neurocircuitry and receptor subtypes mediating anxiolytic-like effects of neuropeptide Y. Neurosci Biobehav Rev 2002, 26:259-283.

70. Missig G, Ayers LW, Schulkin J, Rosen JB: Oxytocin reduces background anxiety in a fear-potentiated startle paradigm. Neuropsychopharmacology 2010, 35:2607-2616.

71. Trent NL, Menard JL: Infusions of neuropeptide $Y$ into the lateral septum reduce anxiety-related behaviors in the rat. Pharmacol Biochem Behav 2011, 99:580-590.

72. Onaka T, Takayanagi Y, Yoshida M: Roles of oxytocin neurones in the control of stress, energy metabolism, and social behaviour. J Neuroendocrinol 2012, 24:587-598.

73. Meyer-Lindenberg A, Domes G, Kirsch P, Heinrichs M: Oxytocin and vasopressin in the human brain: social neuropeptides for translational medicine. Nat Rev Neurosci 2011, 12:524-538.

74. Labuschagne I, Phan KL, Wood A, Angstadt M, Chua P, Heinrichs M, Stout JC, Nathan PJ: Oxytocin attenuates amygdala reactivity to fear in generalized social anxiety disorder. Neuropsychopharmacology 2010, 35:2403-2413.

75. Petrovic $P$, Kalisch R, Singer T, Dolan RJ: Oxytocin attenuates affective evaluations of conditioned faces and amygdala activity. J Neurosci 2008 28:6607-6615

76. Donner J, Sipila T, Ripatti S, Kananen L, Chen X, Kendler KS, Lonnqvist J, Pirkola S, Hettema JM, Hovatta I: Support for involvement of glutamate decarboxylase 1 and neuropeptide $Y$ in anxiety susceptibility. Am J Med Genet B Neuropsychiatr Genet 2012, 159B:316-327.

77. Wendelaar Bonga SE: The stress response in fish. Physiol Rev 1997, 77:591-625.

78. Barton BA: Stress in fishes: a diversity of responses with particular reference to changes in circulating corticosteroids. Integr Comp Biol 2002, 42:517-525.

79. Alsop D, Vijayan MM: Molecular programming of the corticosteroid stress axis during zebrafish development. Comp Biochem Physiol A Mol Integr Physiol 2009, 153:49-54.

80. Fekete EM, Zorrilla EP: Physiology, pharmacology, and therapeutic relevance of urocortins in mammals: ancient CRF paralogs. Front Neuroendocrinol 2007, 28:1-27.

81. Pan W, Kastin AJ: Urocortin and the brain. Prog Neurobio/ 2008, 84:148-156.

82. Gysling K, Forray MI, Haeger P, Daza C, Rojas R: Corticotropin-releasing hormone and urocortin: redundant or distinctive functions? Brain Res Brain Res Rev 2004, 47:116-125.

83. Neufeld-Cohen A, Tsoory MM, Evans AK, Getselter D, Gil S, Lowry CA, Vale WW, Chen A: A triple urocortin knockout mouse model reveals an essential role for urocortins in stress recovery. Proc Natl Acad Sci USA 2010, 107:19020-19025.

84. Spina MG, Merlo-Pich E, Akwa Y, Balducci C, Basso AM, Zorrilla EP, Britton KT, Rivier J, Vale WW, Koob GF: Time-dependent induction of anxiogeniclike effects after central infusion of urocortin or corticotropin-releasing factor in the rat. Psychopharmacology (Berl) 2002, 160:113-121.

85. Gehlert DR, Shekhar A, Morin SM, Hipskind PA, Zink C, Gackenheimer SL Shaw J, Fitz SD, Sajdyk TJ: Stress and central Urocortin increase anxietylike behavior in the social interaction test via the CRF1 receptor. Eur J Pharmacol 2005, 509:145-153.

86. Moreau JL, Kilpatrick G, Jenck F: Urocortin, a novel neuropeptide with anxiogenic-like properties. Neuroreport 1997, 8:1697-1701.

87. Slawecki CJ, Somes C, Rivier JE, Ehlers CL: Neurophysiological effects of intracerebroventricular administration of urocortin. Peptides 1999, 20:211-218

88. Sajdyk TJ, Schober DA, Gehlert DR, Shekhar A: Role of corticotropinreleasing factor and urocortin within the basolateral amygdala of rats in anxiety and panic responses. Behav Brain Res 1999, 100:207-215.

89. Venihaki M, Sakihara S, Subramanian S, Dikkes P, Weninger SC, Liapakis G, Graf T, Majzoub JA: Urocortin III, a brain neuropeptide of the corticotropin-releasing hormone family: modulation by stress and attenuation of some anxiety-like behaviours. J Neuroendocrinol 2004 16:411-422.

90. Jamieson PM, Li C, Kukura C, Vaughan J, Vale W: Urocortin 3 modulates the neuroendocrine stress response and is regulated in rat amygdala and hypothalamus by stress and glucocorticoids. Endocrinology 2006, 147:4578-4588.

91. Deussing JM, Breu J, Kuhne C, Kallnik M, Bunck M, Glasl L, Yen YC, Schmidt MV, Zurmuhlen R, Vogl AM, et al: Urocortin 3 modulates social discrimination abilities via corticotropin-releasing hormone receptor type 2. J Neurosci 2010, 30:9103-9116.

92. Lennartsson AK, Jonsdottir $\mathrm{H}$ : Prolactin in response to acute psychosocial stress in healthy men and women. Psychoneuroendocrinology 2011, 36:1530-1539.

93. Diaz-Moran S, Palencia M, Mont-Cardona C, Canete T, Blazquez G, MartinezMembrives E, Lopez-Aumatell R, Tobena A, Fernandez-Teruel A: Coping style and stress hormone responses in genetically heterogeneous rats: comparison with the Roman rat strains. Behav Brain Res 2012, 228:203-210.

94. Torner L, Neumann ID: The brain prolactin system: involvement in stress response adaptations in lactation. Stress 2002, 5:249-257.

95. Pottinger TG, Prunet P, Pickering AD: The effects of confinement stress on circulating prolactin levels in rainbow trout (Oncorhynchus mykiss) in fresh water. Gen Comp Endocrinol 1992, 88:454-460.

96. Avella M, Schreck CB, Prunet P: Plasma prolactin and cortisol concentrations of stressed coho salmon, Oncorhynchus kisutch, in fresh water or salt water. Gen Comp Endocrinol 1991, 81:21-27.

97. Liu GX, Cai GQ, Cai YQ, Sheng ZJ, Jiang J, Mei Z, Wang ZG, Guo L, Fei J: Reduced anxiety and depression-like behaviors in mice lacking GABA transporter subtype 1. Neuropsychopharmacology 2007, 32:1531-1539.

98. Mennigen JA, Martyniuk CJ, Crump K, Xiong H, Zhao E, Popesku J, Anisman H, Cossins AR, Xia X, Trudeau VL: Effects of fluoxetine on the reproductive axis of female goldfish (Carassius auratus). Physiol Genomics 2008, 35:273-282.

99. Benton CS, Miller BH, Skwerer S, Suzuki O, Schultz LE, Cameron MD, Marron JS, Pletcher MT, Wiltshire T: Evaluating genetic markers and neurobiochemical analytes for fluoxetine response using a panel of mouse inbred strains. Psychopharmacology (Berl) 2012, 221:297-315.

100. Huang GJ, Ben-David E, Tort Piella A, Edwards A, Flint J, Shifman S: Neurogenomic evidence for a shared mechanism of the antidepressant effects of exercise and chronic fluoxetine in mice. PLoS One 2012, 7:e35901.

101. Lee JH, Ko E, Kim YE, Min JY, Liu J, Kim Y, Shin M, Hong M, Bae H: Gene expression profile analysis of genes in rat hippocampus from antidepressant treated rats using DNA microarray. BMC Neurosci 2010, 11:152.

102. Griffith M, Griffith OL, Mwenifumbo J, Goya R, Morrissy AS, Morin RD, Corbett R, Tang MJ, Hou YC, Pugh TJ, et al: Alternative expression analysis by RNA sequencing. Nat Methods 2010, 7:843-847.

103. Morey JS, Ryan JC, Van Dolah FM: Microarray validation: factors influencing correlation between oligonucleotide microarrays and realtime PCR. Biol Proced Online 2006, 8:175-193.

104. Hawlena D, Schmitz OJ: Herbivore physiological response to predation risk and implications for ecosystem nutrient dynamics. Proc Natl Acad Sci USA 2010, 107:15503-15507.

105. Lima SL, Anders Pape MÃ Iler MM, Peter JBS: Stress and Decision Making under the Risk of Predation: Recent Developments from Behavioral, Reproductive, and Ecological Perspectives. In Advances in the Study of Behavior. Volume, Volume Volume 27. San Diego, CA USA: Academic Press Inc; 1998:215-290.

106. Santos EM, Kille P, Workman VL, Paull GC, Tyler CR: Sexually dimorphic gene expression in the brains of mature zebrafish. Comp Biochem Physiol A Mol Integr Physiol 2008, 149:314-324.

107. Toth AL, Varala K, Newman TC, Miguez FE, Hutchison SK, Willoughby DA, Simons JF, Egholm M, Hunt JH, Hudson ME, Robinson GE: Wasp gene expression supports an evolutionary link between maternal behavior and eusociality. Science 2007, 318:441-444.

108. Sen Sarma M, Whitfield CW, Robinson GE: Species differences in brain gene expression profiles associated with adult behavioral maturation in honey bees. BMC Genomics 2007, 8:202

109. Whitfield CW, Cziko A-M, Robinson GE: Gene expression profiles in the brain predict behavior in individual honey bees. Science (Washington D C) 2003, 302:296-299.

110. Aubin-Horth N, Landry CR, Letcher BH, Hofmann HA: Alternative life histories shape brain gene expression profiles in males of the same population. Proc Biol Sci 2005, 272:1655-1662.

111. Renn SC, Aubin-Horth N, Hofmann HA: Fish and chips: functional genomics of social plasticity in an African cichlid fish. J Exp Biol 2008, 211:3041-3056.

112. Sanogo YO, Hankison S, Band M, Obregon A, Bell AM: Brain transcriptomic response of threespine sticklebacks to cues of a predator. Brain Behav Evol 2011, 77:270-285. 
113. Catalan A, Hutter S, Parsch J: Population and sex differences in Drosophila melanogaster brain gene expression. BMC Genomics 2012, 13:654.

114. Drew RE, Settles ML, Churchill EJ, Williams SM, Balli S, Robison BD: Brain transcriptome variation among behaviorally distinct strains of zebrafish (Danio rerio). BMC Genomics 2012, 13:323.

115. Wong RY, Ramsey ME, Cummings ME: Localizing brain regions associated with female mate preference behavior in a swordtail. PLOS One 2012, 7:e50355.

116. Fitzpatrick MJ, Ben-Shahar Y, Smid HM, Vet LEM, Robinson GE, Sokolowski MB: Candidate genes for behavioural ecology. Trends Ecol Evol 2005, 20:96-104.

117. Wada K, Howard JT, McConnell P, Whitney O, Lints T, Rivas MV, Horita H, Patterson MA, White SA, Scharff C, et al: A molecular neuroethological approach for identifying and characterizing a cascade of behaviorally regulated genes. Proc Natl Acad Sci USA 2006, 103:15212-15217.

118. Kanehisa M, Goto S, Sato Y, Furumichi M, Tanabe M: KEGG for integration and interpretation of large-scale molecular data sets. Nucleic Acids Res 2012, 40:D109-D114.

119. Kanehisa M, Goto S: KEGG: kyoto encyclopedia of genes and genomes. Nucleic Acids Res 2000, 28:27-30.

120. Mennigen JA, Lado WE, Zamora JM, Duarte-Guterman P, Langlois VS, Metcalfe CD, Chang JP, Moon TW, Trudeau VL: Waterborne fluoxetine disrupts the reproductive axis in sexually mature male goldfish, Carassius auratus. Aquat Toxicol 2010, 100:354-364.

121. Gunn BG, Brown AR, Lambert JJ, Belelli D: Neurosteroids and GABA(A) Receptor Interactions: A Focus on Stress. Front Neurosci 2011, 5:131.

122. Zimmerberg B, Brunelli SA, Hofer MA: Reduction of rat pup ultrasonic vocalizations by the neuroactive steroid allopregnanolone. Pharmacol Biochem Behav 1994, 47:735-738.

123. Akwa Y, Purdy RH, Koob GF, Britton KT: The amygdala mediates the anxiolytic-like effect of the neurosteroid allopregnanolone in rat. Behav Brain Res 1999, 106:119-125.

124. Evans J, Sun Y, McGregor A, Connor B: Allopregnanolone regulates neurogenesis and depressive/anxiety-like behaviour in a social isolation rodent model of chronic stress. Neuropharmacology 2012, 63:1315-1326.

125. Engin $E$, Treit $D$ : The anxiolytic-like effects of allopregnanolone vary as a function of intracerebral microinfusion site: the amygdala, medial prefrontal cortex, or hippocampus. Behav Pharmacol 2007, 18:461-470.

126. Homberg JR, Olivier JD, Blom T, Arentsen T, van Brunschot C, Schipper P, Korte-Bouws $\mathrm{G}$, van Luijtelaar $\mathrm{G}$, Reneman L: Fluoxetine exerts agedependent effects on behavior and amygdala neuroplasticity in the rat. PLoS One 2011, 6:e16646.

127. Bouet V, Klomp A, Freret T, Wylezinska-Arridge M, Lopez-Tremoleda J, Dauphin F, Boulouard M, Booij J, Gsell W, Reneman L: Age-dependent effects of chronic fluoxetine treatment on the serotonergic system one week following treatment. Psychopharmacology (Berl) 2012, 221:329-339.

128. Olivier JD, Blom T, Arentsen T, Homberg JR: The age-dependent effects of selective serotonin reuptake inhibitors in humans and rodents: A review. Prog Neuropsychopharmacol Biol Psychiatry 2011, 35:1400-1408.

doi:10.1186/1471-2164-14-348

Cite this article as: Wong et al:: Behavioral and neurogenomic transcriptome changes in wild-derived zebrafish with fluoxetine treatment. BMC Genomics 2013 14:348.

\section{Submit your next manuscript to BioMed Central and take full advantage of:}

- Convenient online submission

- Thorough peer review

- No space constraints or color figure charges

- Immediate publication on acceptance

- Inclusion in PubMed, CAS, Scopus and Google Scholar

- Research which is freely available for redistribution 